\title{
The influence of the gut microflora on protein synthesis in liver and jejunal mucosa in chicks
}

\author{
By T. MURAMATSU*, M. E. COATES, D. HEWITT $\dagger$ AND D. N. SALTER \\ National Institute for Research in Dairying, Shinfield, Reading, Berkshire RG2 9AT
}

AND P. J. GARLICK

Clinical Nutrition and Metabolism Unit, 4 St Pancras Way, London NWI 2PE

(Received 10 June 1982 - Accepted 10 December 1982)

\begin{abstract}
1. Protein synthesis in liver and jejunal mucosa was measured in 19-d-old germ-free (GF) and conventional (CV) chicks fed on a semi-purified casein-gelatin (SCG) diet using a massive-dose single injection of [U${ }^{14}$ Clphenylalanine. The effect of subsequent feeding for $9 \mathrm{~d}$ either a nitrogen-free (NF) diet or an NF diet supplemented with L-methionine $(5 \mathrm{~g} / \mathrm{kg})$ and L-arginine hydrochloride $(2 \mathrm{~g} / \mathrm{kg})$ (MA diet) was investigated in both types of chick.

2. In the liver, apart from the amount of DNA, the values for wet weight, protein, RNA, fractional synthesis rate (FSR) and the amount of protein synthesized were reduced after feeding the NF diet and, to a lesser extent, the MA diet. Except that the total amount of liver DNA was higher in the CV chicks than in their GF counterparts $(P<0.01)$, no environmental effect was significant. When expressed on a unit body-weight basis, liver weight, protein, RNA and DNA were significantly higher in the CV than in the GF chicks.

3. In the jejunal mucosa, the values for wet weight, protein and RNA tended to be reduced after the NF treatment but increased after the MA treatment. Mucosal DNA and the amount of protein synthesized $(\mu \mathrm{g} / \mathrm{mm}$ per d) were significantly reduced after the NF diet but were less affected after the MA diet. Mucosal protein FSR and the amount of protein synthesized per mg RNA were significantly reduced after both dietary treatments. No difference was found among dietary treatments in the amount of protein synthesized per mg DNA in jejunal mucosa. Mucosal DNA was significantly higher in the CV chicks and the reverse was true for mucosal protein: DNA.

4. It was suggested that the increased protein synthesis in jejunal mucosa and possibly in liver on supplementation of an NF diet with methionine and arginine would partly, if not completely, account for the N-sparing effect of these amino acids.

5. Although the protein:DNA value was smaller in CV chicks, the FSR and the amount of protein synthesized tended to be higher than in their GF counterparts irrespective of nutritional status. This might imply that protein degradation rate is greater in the CV state.
\end{abstract}

In the conventional (CV) bird, organs such as the gastrointestinal tract which harbour a heavy burden of micro-organisms differ from their germ-free (GF) counterparts in some characteristics. For instance, the small intestinal wall is thicker in the CV chicks, mainly because of an increased amount of connective tissue (Gordon \& Bruckner-Kardoss, 1961) and the migration rate of the mucosal epithelial cells is faster (Cook \& Bird, 1973; Rolls et al. 1978). The liver of CV birds is sometimes, though not always, heavier (Reyniers et al. 1960), possibly because some of the end-products of microbial activity in the gut such as ammonia (Visek, 1974) and amines (Cheeseman \& Fuller, 1966) are detoxified in the liver.

On a nitrogen-free (NF) diet, Salter et al. (1974) found that more $N$ was lost in the excreta by GF chicks than by their CV controls, suggesting that the activities of the gut microflora conserve $\mathrm{N}$ for the host. In similar circumstances, Okumura et al. (1978) reported differences in faecal amino acid composition between birds in the two environments. There was evidence of synthesis of some essential amino acids by the gut microflora which might partly

* Present address: Laboratory of Animal Nutrition, Faculty of Agriculture, Nagoya University, Chikusa-ku, Nagoya 464, Japan.

+ For reprints. 
account for the lower $\mathrm{N}$ excretion of $\mathrm{CV}$ chicks in protein starvation. This $\mathrm{N}$-sparing effect is likely to be brought about by enhanced protein synthesis in tissues through increased re-utilization of endogenously-formed amino acids or by decreased body protein degradation, or both.

The present study was done to examine whether the presence of the gut microflora affects protein synthesis in liver and jejunal mucosa and to what extent supplementation of an NF diet with methionine and arginine influences protein synthesis in these tissues in GF and CV chicks.

\section{MATERIALS AND METHODS}

\section{Chicks}

GF chicks of the Rhode Island Red $\times$ Light Sussex cross were reared in large Gustafsson stainless-steel isolators as described by Coates et al. (1963). CV birds from the same hatch of eggs were kept in a clean but non-sterile room where the physical environment could be maintained to match that present within the isolators. Both GF and CV chicks were housed in groups of four birds in stainless-steel cages with mesh floors, and males and females were distributed evenly among the experimental groups. The continued microbial sterility of the birds within isolators was checked at intervals (Fuller, 1968).

Diet. The composition $(\mathrm{g} / \mathrm{kg}$ ) of the semi-purified, casein-gelatin (SCG) diet was: maize starch 596.5 , casein 180 , gelatin 100 , salt mixture 60 , L-cystine $3 \cdot 0$, choline chloride $1 \cdot 5$, myo-inositol $1 \cdot 0$, vitamin supplement $8 \cdot 0$, maize oil 50 . The salt mixture supplied $(/ \mathrm{kg} \mathrm{diet})$ : $\mathrm{CaCO}_{3} 17 \cdot 1 \mathrm{~g}, \mathrm{CaHPO}_{4} .2 \mathrm{H}_{2} \mathrm{O} 17 \cdot 1 \mathrm{~g}, \mathrm{KH}_{2} \mathrm{PO}_{4} 13.3 \mathrm{~g}, \mathrm{NaCl} 8.67 \mathrm{~g}, \mathrm{MgSO}_{4} \cdot \mathrm{H}_{2} \mathrm{O}$ $2.67 \mathrm{~g}, \mathrm{FeSO}_{4} .7 \mathrm{H}_{2} \mathrm{O} 670 \mathrm{mg}, \mathrm{MnSO}_{4} .4 \mathrm{H}_{2} \mathrm{O} 270 \mathrm{mg}, \mathrm{ZnSO}_{4} .7 \mathrm{H}_{2} \mathrm{O} 130 \mathrm{mg}, \mathrm{KI} 37 \mathrm{mg}$, $\mathrm{CuSO}_{4} .5 \mathrm{H}_{2} \mathrm{O} 16 \mathrm{mg}$. Fat-soluble vitamins dissolved in maize oil provided $(\mathrm{mg} / \mathrm{kg}$ diet): cholecalciferol 0.16, menaphthone 20, $\alpha$-tocopheryl acetate 40. Rovimix A500 (Roche Products, Welwyn Garden City, Herts) was added to supply $20 \mathrm{mg}$ retinol $/ \mathrm{kg}$ diet. The vitamin supplement provided $(\mathrm{mg} / \mathrm{kg}$ diet): biotin $0 \cdot 8$, pteroylmonoglutamic acid $6 \cdot 0$, thiamin hydrochloride $12 \cdot 0$, pyridoxin hydrochloride $16 \cdot 0$, riboflavin $24 \cdot 0$, calcium pantothenate $60 \cdot 0$, nicotinic acid $160 \cdot 0$, cyanocobalamin $0 \cdot 08$. In the case of the NF diet, casein, gelatin and L-cystine were replaced by methylcellulose $(10 \mathrm{~g})$ and maize starch $(273 \mathrm{~g})$. For the MA diet supplements $(\mathrm{g} / \mathrm{kg})$ of $\mathrm{L}$-methionine 5 and $\mathrm{L}$-arginine hydrochloride 2 were added at the expense of maize starch in the NF diet. After mixing, all the diets were granulated, packed into plastic bags and sterilized by gamma radiation at $5 \mathrm{Mrad}$. Vitamin supplements were high to compensate for possible destruction during irradiation.

\section{Experimental procedure}

The birds were maintained in both environments on the SCG diet until $18 \mathrm{~d}$ of age. Four birds in each environment were then taken for measurement of protein synthesis. To ensure that they had taken food on the day of test they were fasted during the previous night and then allowed to eat for more than $2 \mathrm{~h}$. The remaining eight birds in each environment were distributed into two groups of four and given either the NF or MA diet for $9 \mathrm{~d}$. Protein synthesis was measured on day 28 , after the same fasting and re-feeding procedure, and the values were compared with those found on day 19 with the adequate diet. This experiment was repeated and the results from both were combined.

\section{Measurement of protein synthesis}

The method was based on that of McNurlan et al. (1979) and depends on the measurement of radioactivity in free and protein-bound phenylalanine of tissues after injection of a single massive dose of labelled phenylalanine. Radioactive $\mathrm{L}-\left[\mathrm{U}-{ }^{14} \mathrm{C}\right]$ phenylalanine $(521 \mathrm{mCi} / \mathrm{mmol})$ (The Radiochemical Centre, Amersham, Bucks) was combined with 
unlabelled L-phenylalanine to give respectively $10 \mu \mathrm{Ci}$ and $100 \mu \mathrm{mol} / \mathrm{ml}$ physiological saline (8.5 g sodium chloride/l) and injected into a wing vein at a dose of $10 \mathrm{ml} / \mathrm{kg}$ bodyweight. GF birds were removed from the isolator just before injection. At 2 and $10 \mathrm{~min}$ after the injection birds were killed by dislocation of the neck, and liver and jejunum, i.e. the part of the small intestine from the entry of the bile ducts to the yolk stalk, were removed quickly. The liver was weighed and then frozen by planging into liquid $\mathrm{N}_{2}$. The length of the jejunum was measured while extended with a $12.8 \mathrm{~g}$ weight. It was then cut longitudinally and rinsed thoroughly in ice-cold saline, blotted and weighed and placed on an ice-cold glass plate. The mucosa was scraped off with a microscope slide and transferred to Petri dishes containing $3 \mathrm{ml}$ of either ice-cold trichloroacetic acid solution $(100 \mathrm{~g} / \mathrm{l})$ for the measurement of specific radioactivity or perchloric acid solution $(20 \mathrm{~g} / \mathrm{l})$ for the measurement of tissue composition.

Calculation of the fractional synthesis rate (FSR) of protein, i.e. the proportion of the protein mass which is replaced each day $\times 100$, was done using the formula described by McNurlan et al. (1979). The time taken from killing the bird to freezing the tissue was approximately $45 \mathrm{~s}$ and allowance was made for this in the calculation.

\section{Chemical analysis}

Tissue composition was determined by the procedure of Lowry et al. (1951) for protein, a modified Schmidt-Thannhauser method for RNA as described by Munro \& Fleck (1969) and the diphenylamine method for DNA as modified by Giles \& Myers (1965). The specific radioactivity of free phenylalanine in the tissue was determined by the method of Garlick et al. (1980). The specific radioactivity of protein-bound phenylalanine was determined similarly after extensive washing of the precipitate with trichloroacetic acid and $\mathrm{HClO}_{4}$ solutions followed by hydrolysis in $6 \mathrm{M}$-hydrochloric acid at $110^{\circ}$ for $24 \mathrm{~h}$. All measurements for radioactivity were made on a Packard Tri-Carb liquid scintillation spectrometer with Instagel (Packard Instruments Ltd, Caversham, Berks) as a scintillator until 5000 counts were accumulated or for $\mathbf{4 0} \mathrm{min}$.

\section{Statistical treatment}

Analysis of variance was carried out to assess the significance of treatment and sex effects. The treatment factors were environment $(1 \mathrm{df})$ and diet $(2 \mathrm{df})$, with interaction environment.diet $(2 \mathrm{df})$. The sex effect $(1 \mathrm{df})$, and the sex.treatment interaction $(5 \mathrm{df})$ which were not significant, are not reported. The standard errors of differences given in the tables were calculated using the interaction between experiments, sexes and treatments $(11 \mathrm{df})$ as the error term.

\section{RESULTS}

Throughout the experimental period the birds in the GF isolators remained uncontaminated according to the tests described by Fuller (1968).

The body-weight of the chicks at $28 \mathrm{~d}$ of age, after being given the NF diet (Table 1), was significantly lower than that of 18 -d-old chicks that had received the SCG diet only $(P<0.01)$. The lowered body-weight of the chicks fed on the NF diet was alleviated by supplementing with methionine and arginine, and a significant difference between the NF and MA groups was found $(P<0.01)$. There was a tendency towards higher body-weight in the GF birds than in their CV counterparts throughout the dietary treatments, but no significant differences were established.

Liver. The values for liver weight, and the contents of protein, RNA and DNA are also given in Table 1. In absolute amounts, no differences were found between environments except in DNA content, which was higher in the CV than GF chicks $(P<0.01)$. In birds 


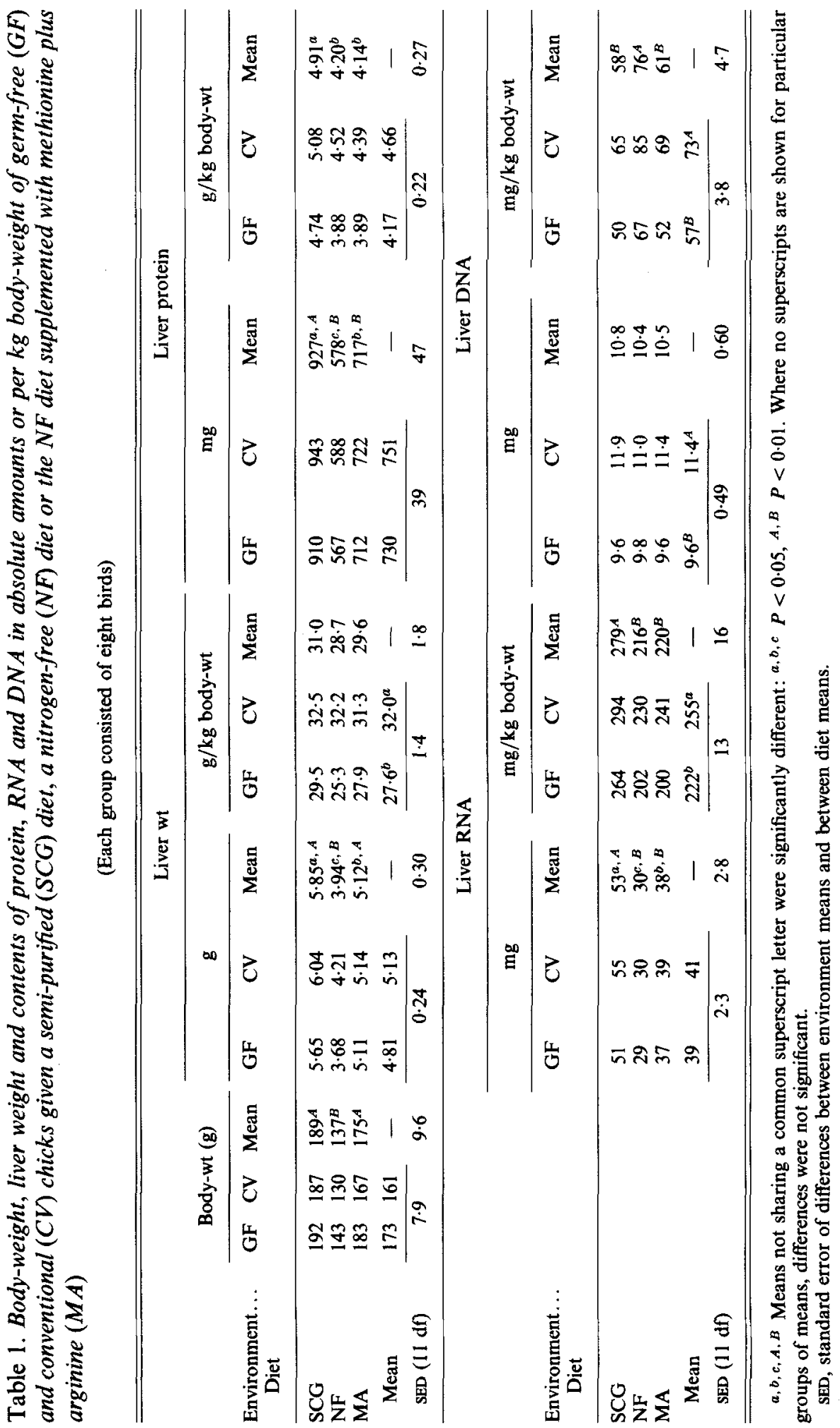


Table 2. RNA:protein, protein:DNA and RNA:DNA values in the liver of germ-free $(G F)$ and conventional $(C V)$ chicks given a semi-purified (SCG) diet, a nitrogen-free (NF) diet or the $N F$ diet supplemented with methionine plus arginine $(M A)$

(Each group consisted of eight birds)

\begin{tabular}{|c|c|c|c|c|c|c|c|c|c|}
\hline \multirow[b]{2}{*}{$\begin{array}{l}\text { Environment... } \\
\text { Diet }\end{array}$} & \multicolumn{3}{|c|}{$\begin{array}{l}\text { Liver RNA }\left(\times 10^{3}\right) \text { : protein } \\
(\mathrm{mg} / \mathrm{g})\end{array}$} & \multicolumn{3}{|c|}{ Liver protein:DNA $(\mathrm{mg} / \mathrm{mg})$} & \multicolumn{3}{|c|}{ Liver RNA: DNA (mg/mg) } \\
\hline & GF & $\mathrm{CV}$ & Mean & GF & $\mathrm{CV}$ & Mean & GF & $\mathrm{CV}$ & Mean \\
\hline SCG & 56 & 58 & $57^{a, A}$ & 97 & 80 & $88^{a, A}$ & $5 \cdot 4$ & $4 \cdot 6$ & $5 \cdot 0^{-4}$ \\
\hline NF & 52 & 51 & $52^{b, B}$ & 59 & 54 & $56^{b, B}$ & $3 \cdot 0$ & 2.7 & $2 \cdot 9^{B}$ \\
\hline MA & 52 & 55 & $53^{b, A B}$ & 75 & 64 & $70^{b, A B}$ & $3 \cdot 9$ & $3 \cdot 5$ & $3 \cdot 7^{B}$ \\
\hline \multirow{2}{*}{$\begin{array}{l}\text { Mean } \\
\text { SED }(11 \mathrm{df})\end{array}$} & 53 & 55 & \multirow{2}{*}{$\overline{1.7}$} & 77 & 66 & \multirow{2}{*}{$\overline{6.5}$} & $4-1$ & $3 \cdot 6$ & \multirow{2}{*}{$\overline{0.42}$} \\
\hline & \multicolumn{2}{|c|}{1.4} & & \multicolumn{2}{|c|}{$5 \cdot 3$} & & \multicolumn{2}{|c|}{0.34} & \\
\hline
\end{tabular}

$a, b, A, B$ Means not sharing a common superscript letter were significantly different: $a, b P<0.05,{ }^{A}, B P<0.01$. Where no superscripts are shown for particular groups of means, differences were not significant.

SED, standard error of differences between environment means and between diet means.

given the NF diet, total liver weight, protein and RNA contents were lower $(P<0.01)$ than had been found on the SCG diet, and the MA group showed intermediate values. When expressed on a unit body-weight basis, the values for relative liver weight and contents of RNA and DNA were significantly higher, and that for relative liver protein almost so, in $\mathrm{CV}$ birds. The dietary effect was less obvious, but relative liver protein and RNA contents were reduced by the NF and MA treatments $(P<0.05$ and 0.01 respectively), and the relative liver DNA content was higher in the NF group than in the other groups $(P<0 \cdot 01)$.

The values for RNA: protein, protein:DNA and RNA:DNA in the liver are shown in Table 2. There was a tendency towards higher protein:DNA values in the GF birds than in the $\mathrm{CV}$ birds, but the difference just failed to reach statistical significance. The values for RNA $\left(\times 10^{3}\right)$ : protein and RNA:DNA were significantly lowered after feeding both NF and MA diets and protein:DNA was lowered after the NF diet.

The FSR of liver protein, the total amount of protein synthesized, and the amounts synthesized/d per mg RNA or DNA are given in Table 3. Although no significant differences were found between environments for these values, the FSR and the amount of protein synthesized $(\mathrm{mg} / \mathrm{d}$ and $\mathrm{g} / \mathrm{kg}$ body-weight per $\mathrm{d}$ ) tended to be higher in the $\mathrm{CV}$ birds than in their GF counterparts. Protein starvation by feeding the NF diet reduced these values and significant differences $(P<0.01)$ were found in the FSR, the absolute amount of protein synthesized, and the amount synthesized/d per mg DNA. The addition of methionine and arginine tended to offset the reduction by the NF diet, but not significantly.

Jejunal mucosa. The values for mucosal weight, and the contents of protein, RNA, and DNA are given in Table 4. These values are expressed in terms of unit length of jejunum since Yokota \& Coates (1982) found no differences in the small intestinal length between GF and CV birds. However, the wet weight was greater in CV chicks, reflecting a thicker gut wall induced by the presence of the gut micro-organisms. The mucosal DNA content $(\mu \mathrm{g} / \mathrm{mm})$ was higher in the $\mathrm{CV}$ birds than in their GF counterparts $(P<0.05)$. The values for the rest of the measurements showed a similar trend but were not significant. The values for mucosal wet weight, and the contents of protein and RNA, tended to be reduced after the NF treatment but to be increased after the MA diet. Mucosal DNA was significantly 


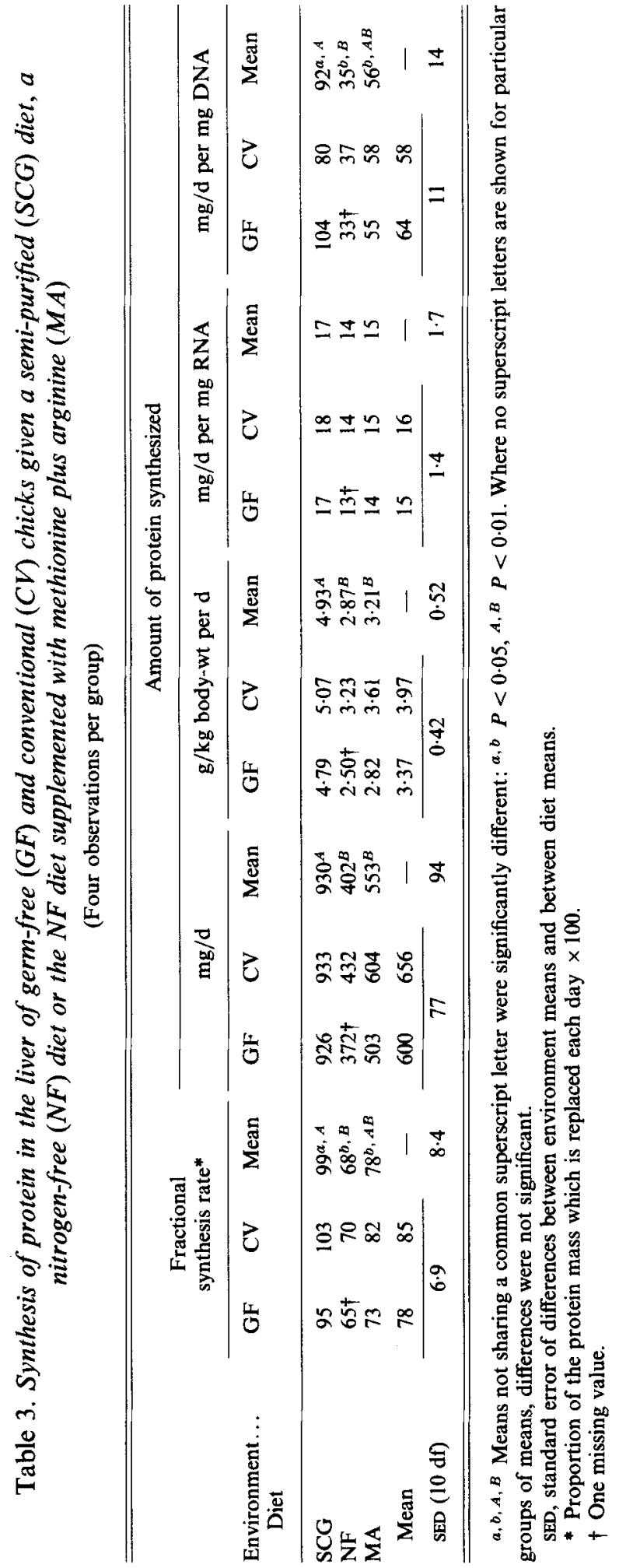


Table 4. Wet weight, protein, RNA and DNA contents of jejunal mucosa in germ-free (GF) and conventional $(C V)$ chicks given a semi-purified (SCG) diet, a nitrogen-free $(N F)$ diet or the $N F$ diet supplemented with methionine plus arginine $(M A)$

(Each group consisted of eight birds)

\begin{tabular}{|c|c|c|c|c|c|c|c|c|c|c|c|c|}
\hline \multirow{2}{*}{$\begin{array}{c}\text { Environ- } \\
\text { ment... } \\
\text { Diet }\end{array}$} & \multicolumn{3}{|c|}{$\begin{array}{c}\text { Mucosal } \\
\text { wt (mg/mm) }\end{array}$} & \multicolumn{3}{|c|}{$\begin{array}{l}\text { Mucosal protein } \\
(\mu \mathrm{g} / \mathrm{mm})\end{array}$} & \multicolumn{3}{|c|}{$\begin{array}{c}\text { Mucosal RNA } \\
(\mu \mathrm{g} / \mathrm{mm})\end{array}$} & \multicolumn{3}{|c|}{$\begin{array}{c}\text { Mucosal DNA } \\
(\mu \mathrm{g} / \mathrm{mm})\end{array}$} \\
\hline & GF & $\mathrm{CV}$ & Mean & GF & $\mathrm{CV}$ & Mean & GF & $\mathrm{CV}$ & Mean & GF & $\mathrm{CV}$ & Mean \\
\hline $\begin{array}{l}\text { SCG } \\
\text { NF } \\
\text { MA }\end{array}$ & $\begin{array}{l}1.70 \\
1.38 \\
2.07\end{array}$ & $\begin{array}{l}1.81 \\
1.67 \\
2.09\end{array}$ & $\begin{array}{l}1 \cdot 76^{A B} \\
1 \cdot 53^{B} \\
2 \cdot 08^{A}\end{array}$ & $\begin{array}{l}241 \\
200 \\
288\end{array}$ & $\begin{array}{l}250 \\
233 \\
271\end{array}$ & $\begin{array}{l}246^{A B} \\
217^{B} \\
280^{A}\end{array}$ & $\begin{array}{r}10 \cdot 9 \\
8.5 \\
12.3\end{array}$ & $\begin{array}{l}11.0 \\
11.2 \\
14.8\end{array}$ & $\begin{array}{c}11 \cdot 0^{b, A B} \\
9 \cdot 9^{b, B} \\
13 \cdot 5^{a, A}\end{array}$ & $\begin{array}{l}4 \cdot 9 \\
2 \cdot 7 \\
4 \cdot 5\end{array}$ & $\begin{array}{l}6 \cdot 0 \\
4 \cdot 1 \\
4 \cdot 9\end{array}$ & $\begin{array}{l}5 \cdot 4^{a, A} \\
3 \cdot 4^{b, B} \\
4 \cdot 7^{a, A B}\end{array}$ \\
\hline Mean & 1.72 & $1 \cdot 86$ & - & 243 & 251 & - & $10 \cdot 5$ & $12 \cdot 3$ & - & $4 \cdot 0^{b}$ & $5 \cdot 0^{a}$ & - \\
\hline $\begin{array}{l}\text { SED } \\
\text { (11 df }\end{array}$ & & 14 & 0.17 & & 4 & $18 \cdot 8$ & & .9 & $1 \cdot 1$ & & 4 & 0.5 \\
\hline
\end{tabular}

$a, b, A, B$ Means not sharing a common superscript letter were significantly different: $a, b P<0.05$, $A, B \quad P<0.01$. Where no superscripts are shown for particular groups of means, differences were not significant. SED, standard errors of differences between environment means and between diet means.

Table 5. RNA : protein, protein: DNA and RNA:DNA values in the jejunal mucosa of germ-free $(G F)$ and conventional ( $C V$ chicks given a semi-purified (SCG) diet, a nitrogen-free $(N F)$ diet or the NF diet supplemented with methionine plus arginine $(M A)$

(Each group consisted of eight birds)

\begin{tabular}{|c|c|c|c|c|c|c|c|c|c|}
\hline \multirow[b]{2}{*}{$\begin{array}{l}\text { Environment ... } \\
\text { Diet }\end{array}$} & \multicolumn{3}{|c|}{$\begin{array}{c}\text { Mucosal RNA } \\
\left(\times 10^{3}\right): \text { protein }(\mathrm{mg} / \mathrm{g})\end{array}$} & \multicolumn{3}{|c|}{$\begin{array}{c}\text { Mucosal protein:DNA } \\
\text { (mg/mg) }\end{array}$} & \multicolumn{3}{|c|}{$\begin{array}{l}\text { Mucosal RNA:DNA } \\
\text { (mg/mg) }\end{array}$} \\
\hline & GF & $\mathrm{CV}$ & Mean & GF & $\mathrm{CV}$ & Mean & $G F$ & $\mathrm{CV}$ & Mean \\
\hline $\begin{array}{l}\text { SCG } \\
\text { NF } \\
\text { MA }\end{array}$ & $\begin{array}{l}45 \\
42 \\
43\end{array}$ & $\begin{array}{l}44 \\
49 \\
55\end{array}$ & $\begin{array}{l}44 \\
46 \\
49\end{array}$ & $\begin{array}{l}50 \\
75 \\
67\end{array}$ & $\begin{array}{l}42 \\
58 \\
60\end{array}$ & $\begin{array}{l}46^{B} \\
67^{A} \\
63^{A}\end{array}$ & $\begin{array}{l}2.2 \\
3.2 \\
2.8\end{array}$ & $\begin{array}{l}1.8 \\
2.8 \\
3.2\end{array}$ & $\begin{array}{l}2 \cdot 0^{B} \\
3 \cdot 0^{A} \\
3.0^{A}\end{array}$ \\
\hline Mean & $43^{b}$ & $49^{a}$ & - & $64^{a}$ & $53^{b}$ & - & 2.8 & 2.6 & - \\
\hline $\operatorname{SED}(11 \mathrm{df})$ & \multicolumn{2}{|c|}{$2 \cdot 2$} & 2.7 & \multicolumn{2}{|c|}{3.8} & 4.7 & \multicolumn{2}{|c|}{$0 \cdot 12$} & $0 \cdot 15$ \\
\hline
\end{tabular}

$a, b, A, B$ Means not sharing a common superscript letter were significantly different: ${ }^{a, b} P<0.05 ; A, B P<0 \cdot 01$. Where no superscripts are shown for particular groups of means, differences were not significant.

SED, standard error of differences between environment means and between diet means.

lowered after the NF treatment $(P<0.01)$ and the reduction was lessened by the amino acid supplement.

Values for mucosal RNA:protein, protein:DNA and RNA:DNA are shown in Table 5. RNA $\left(\times 10^{3}\right)$ : protein was higher in the CV birds than in their GF controls $(P<0.05)$ while the reverse was true for protein:DNA $(P<0.05)$. No difference was found between environments in RNA:DNA. The values for protein:DNA and RNA:DNA were raised after the two dietary treatments $(P<0.01)$.

The mucosal FSR and the amount of protein synthesized are given in Table 6. As in the liver, although no significant differences were found between environments in these measurements, the mucosal FSR and the amount of protein synthesized $(\mu \mathrm{g} / \mathrm{mm}$ per d) 
Table 6. Synthesis of protein in the jejunal mucosa of germ-free $(G F)$ and conventional $(C V)$ chicks given a semi-purified (SCG) diet, a nitrogen-free $(N F)$ diet or the NF diet supplemented with methionine plus arginine $(M A)$

(Four observations per group)

\begin{tabular}{|c|c|c|c|c|c|c|c|c|c|c|c|c|}
\hline \multirow[b]{3}{*}{$\begin{array}{l}\text { Environment... } \\
\text { Diet }\end{array}$} & \multirow{2}{*}{\multicolumn{3}{|c|}{$\begin{array}{c}\text { Fractional } \\
\text { synthesis rate* }\end{array}$}} & \multicolumn{9}{|c|}{ Amount of protein synthesized } \\
\hline & & & & \multicolumn{3}{|c|}{$\mu \mathrm{g} / \mathrm{mm}$ per $\mathrm{d}$} & \multicolumn{3}{|c|}{$\mathrm{mg} / \mathrm{d}$ per mg RNA } & \multicolumn{3}{|c|}{$\mathrm{mg} / \mathrm{d}$ per mg DNA } \\
\hline & GF & $\mathrm{CV}$ & Mean & GF & $\mathrm{CV}$ & Mean & GF & $\mathrm{CV}$ & Mean & GF & $\mathrm{CV}$ & Mean \\
\hline $\begin{array}{l}\text { SCG } \\
\text { NF } \\
\text { MA }\end{array}$ & $\begin{array}{l}70 \\
60 \dagger \\
51\end{array}$ & $\begin{array}{l}78 \\
56 \\
63\end{array}$ & $\begin{array}{l}74^{A} \\
58^{B} \\
57^{B}\end{array}$ & $\begin{array}{l}158 \\
120 \dagger \\
152\end{array}$ & $\begin{array}{l}191 \\
112 \\
168\end{array}$ & $\begin{array}{l}175^{a, A} \\
116^{b, B} \\
160^{a, A B}\end{array}$ & $\begin{array}{l}16 \\
14 \dagger \\
12\end{array}$ & $\begin{array}{l}17 \\
12 \\
12\end{array}$ & $\begin{array}{l}16^{a, A} \\
13^{b, A B} \\
12^{b, B}\end{array}$ & $\begin{array}{l}34 \\
44 \uparrow \\
35\end{array}$ & $\begin{array}{l}32 \\
31 \\
36\end{array}$ & $\begin{array}{l}33 \\
37 \\
36\end{array}$ \\
\hline Mean & 60 & 66 & - & 143 & 157 & - & 14 & 13 & - & 38 & 33 & - \\
\hline $\operatorname{SED}(10 \mathrm{df})$ & \multicolumn{2}{|c|}{$3 \cdot 2$} & $4 \cdot 0$ & \multicolumn{2}{|c|}{11} & 14 & \multicolumn{2}{|c|}{0.8} & $1 \cdot 0$ & \multicolumn{2}{|c|}{$2 \cdot 6$} & $3 \cdot 2$ \\
\hline
\end{tabular}

$a, b, A, B$ Means not sharing a common superscript letter were significantly different: ${ }^{a, b} P<0.05, A, B P<0.01$.

Where no superscript letters are shown for particular groups of means, differences were not significant. SED, standard error of differences between environment means and between diet means.

* Proportion of the protein mass which is replaced each day $\times 100$.

$\uparrow$ One missing value.

tended to be higher in the CV than in the GF chicks. The mucosal FSR and the amount of protein synthesized/d per mg RNA were reduced after feeding the NF diet $(P<0.01$ and 0.05 respectively) and MA diet $(P<0.01)$, and the amount of protein synthesized $/ \mathrm{mm}$ jejunum per $\mathrm{d}$ by the chicks after being fed on the NF diet was significantly lowered $(P<0.01)$.

\section{DISCUSSION}

In general, the growth of GF birds fed on an adequate diet is faster than that of CV birds, while the body-weight loss of GF birds given an NF diet is greater and more $\mathrm{N}$ is excreted than by their CV counterparts (Coates, 1968; Salter et al. 1974; Okumura et al. 1978). These effects were not apparent in the present study probably because the numbers involved were insufficient to be representative for growth. Nevertheless, the smaller body-weight loss in the CV chicks fed on the MA diet compared with those on the NF diet is in agreement with the finding of Muramatsu \& Okumura (1979). This effect was also observed in the GF environment.

The supplementation of the NF diet with methionine and arginine increased the amount of protein synthesized in jejunal mucosa and possibly in the liver. This would account for part, if not all, the $\mathrm{N}$-sparing effect of these amino acids observed by Muramatsu \& Okumura (1979). The effect could be brought about through an increased rate of re-utilization of endogenously-formed amino acids from body-protein breakdown.

In the present experiment, some effect of ageing might have contributed to the differences found between values on the SCG diet (19-d-old chicks) and the NF or MA diets 28-d-old chicks). However, in rat liver, no developmental fall of FSR was found (Waterlow et al. 1978) and it seems likely, therefore, that the lower liver-protein FSR observed after feeding the NF diet compared with the SCG diet (Table 3) mainly reflects the effect of protein deprivation itself. The magnitude of the reduction was of the same order as that found in protein-depleted rats compared with normal control animals (McNurlan \& Garlick, 1981). 
The liver RNA activity (protein synthesized/d per mg RNA) showed a small, non-significant reduction after protein deprivation. This suggests that there may have been a smaller proportion of polyribosome RNA relative to total RNA in protein-depleted chick liver. A larger proportion of monosome and disome relative to total RNA was reported in the protein-depleted rat liver compared with normal controls (Yokogoshi \& Yoshida, 1979).

When the liver weight, and the contents of protein, RNA and DNA were expressed on a unit body-weight basis, the values from the GF birds were generally smaller than those of the CV controls, supporting the findings of Reyniers et al. (1960) who found a smaller liver weight in the absence of the gut microflora. This evidence, together with the tendency towards higher liver FSR and the amount of protein synthesized in the CV environment, supports the assumption of higher activity of the liver in the presence of the gut microfiora, possibly due to the load of toxic substances such as ammonia (Visek, 1974) and amines (Cheeseman \& Fuller, 1966) produced in the gut and transported to the liver to be detoxified. However, the environmental effect on the liver FSR and the amount of protein synthesized failed to reach statistical significance.

The FSR of jejunal mucosa ranged from approximately $50 \%$ to $80 \%$, about half the values of those observed in rats (McNurlan et al. 1979). This is not surprising since the migration time of epithelial cells in the rat intestine was reported to be $41 \mathrm{~h}$ (Gleeson et al. 1972), whereas the corresponding values for the chick intestine would be $180-200 \mathrm{~h}$ according to the results of Rolls et al. (1978). The reduction of approximately $20 \%$ in mucosal FSR by protein depletion agrees with that found in the mucosa of protein-deprived rats (McNurlan \& Garlick, 1981). The migration time of mucosal epithelial cells in GF birds is longer than that of CV controls (Cook \& Bird, 1973; Rolls et al. 1978). A lower FSR of mucosal protein in the GF environment would therefore be expected, and in the present study the mucosal FSR of the GF birds tended to be lower than that of their CV counterparts, although the difference was not statistically significant.

In both liver and jejunal mucosa, higher DNA contents were found in CV chicks compared with those of their GF counterparts (Tables 1 and 4). This higher DNA content in mucosa is consistent with the findings of a higher mitotic index of intestinal epithelium in CV than in GF birds (Rolls et al. 1978). It may be that the increased mitosis in CV birds is caused by increased ammonia concentration in the gastrointestinal tract due to bacterial action on amino acids, urea and uric acid (Salter, 1973). It has been reported that exposure to low concentrations of ammonia increased DNA synthesis in the ileum of the mouse (Zimber \& Visek, 1972). Similarly, if there is a higher concentration of ammonia in the portal venous blood of the chick, as reported in the guinea-pig by Warren \& Newton (1959), this could account for the increased DNA content of the liver.

A lower protein:DNA value was observed in the jejunal mucosa and liver of CV birds (Tables 2 and 5). This might be accounted for by differences in the proportions of the various types of cells. In the GF chick the reticulo-endothelial system is less well developed (Gordon \& Bruckner-Kardoss, 1961) and the mean cell size in the gut and liver is therefore likely to be different from that of the CV chick. Millward et al. (1981) described protein:DNA as functional cell size and considered that the rate of protein synthesis per unit DNA is similar for all cell types. In spite of the lower value in the tissues from CV birds the FSR and absolute amounts of protein synthesized tended to be higher (Tables 3 and 6). This might imply that the protein degradation rate was higher in the tissues of the CV birds, a possibility that remains to be investigated in future studies.

The authors are grateful to Mr J.P. Fordham for care of the birds, and to Mrs R. Anderson for her excellent technical assistance. 


\section{REFERENCES}

Cheeseman, G. C. \& Fuller, R. (1966). J. appl. Bact. 29, 596.

Coates, M. E. (editor) (1968). In The Germ-free Animal in Research, p. 79. London: Academic Press.

Coates, M. E., Fuller, R., Harrison, G. F., Lev, M. \& Suffolk, S. F. (1963). Br. J. Nutr. 17, 141.

Cook, R. H. \& Bird, F. H. (1973). Poult. Sci. 52, 2276.

Fuller, R. (1968). In The Germ-free Animal in Research, p. 37 [M. E. Coates, editor]. London: Academic Press.

Garlick, P. J., McNurlan, M. A. \& Preedy, V. R. (1980). Biochem. J. 192, 719.

Giles, K. W. \& Myers, A. (1965). Nature, Lond. 206, 93.

Gleeson, M. H., Cullen, J. \& Dowling, R. H. (1972). Clin. Sci. 43, 731.

Gordon, H. A. \& Bruckner-Kardoss, E. (1961). Acta Anat. 44, 210.

Lowry, O. H., Rosebrough, N. J., Farr, A. L. \& Randall, R. J. (1951). J. biol. Chem. 193, 265.

McNurlan, M. A. \& Garlick, P. J. (1981). Am. J. Physiol. Endocr. Metab. 4, E238.

McNurlan, M. A., Tomkins, A. M. \& Garlick, P. J. (1979). Biochem. J. 178, 373.

Millward, D. J., Bates, P. C. \& Rosochacki, S. (1981). Reprod. Nutr. Dev. 21, 265.

Munro, H. N. \& Fleck, A. (1969). In Mammalian Protein Metabolism, vol. 3, p. 424 [H. N. Munro, editor]. New York: Academic Press.

Muramatsu, T. \& Okumura, J. (1979). Nutr. Rep. int. 20, 709.

Okumura, J., Hewitt, D. \& Coates, M. E. (1978). Br. J. Nutr. 39, 99.

Reyniers, J. A., Wagner, H., Luckey, T. D. \& Gordon, H. A. (1960). In Lobund Reports, no. 3, p. 57 [R. F. Ervin, H. A. Gordon and M. Wagner, editors]. Indiana: University of Notre Dame Press.

Rolls, B. A., Turvey, A. \& Coates, M. E. (1978). Br. J. Nutr. 39, 91.

Salter, D. N. (1973). Proc. Nutr. Soc. 32, 65.

Salter, D. N., Coates, M. E. \& Hewitt, D. (1974). Br. J. Nutr. 31, 307.

Visek, W. J. (1974). J. agric. Fd Chem. 22, 174.

Warren, K. S. \& Newton, W. L. (1959). Am. J. Physiol. 197, 717.

Waterlow, J. C., Garlick, P. J. \& Millward, D. J. (1978). Protein Turnover in Mammalian Tissues and in the Whole Body, p. 529 Amsterdam: North-Holland Publishing Co.

Yokogoshi, H. \& Yoshida, A. (1979). J. Nutr. 109, 148.

Yokota, H. \& Coates, M. E. (1982). Br. J. Nutr. 47, 349.

Zimber, A. \& Visek, W. J. (1972). Am. J. Physiol. 223, 1004. 